\title{
The Role of Stock Markets in
}

\section{Economic Growth}

Evidence From Emerging Economies, A Panel Data Analysis

\author{
Dr. Abdelmohsen Mostafa Abdallah*
}

(*)* Dr. Abdelmohsen Mostafa Abdallah, Assistance Professor of Economics. Department of Economic Sciences, Faculty of Technology \& Development, Zagazig University

E-mail: mohsen7777777@ hotmail.com 


\section{$\underline{\text { Abstract }}$}

In this Paper the relationship between Stock markets indicators (equity $\&$ bond market indicators) and economic growth in emerging economies is examined. A great focus will be brought on the equity \& bond market, and the relationship between developing such a major stock market indicators and the economic growth will be studied through 16 indicators as proxies of stock market development, for equity market ( 4 for size, 3 for efficiency, and 2 for stability indicators), for bond market ( 3 for size, 2 for efficiency, and 2 for stability indicators). A regression analysis will be applied on a panel data consisting of 5 emerging economies across 5 years to evaluate the possible role of stock markets indicators in the growth of GDP in these economies.

\section{الملخص :}

استهدفت هذه الدراسة اختبار دور سوق الأسهم في النمو الاقتصادي في الاقتصاديات

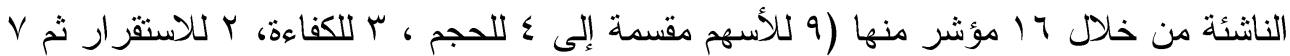
مؤشرات للسندات مقسمة إلى ب للحجم ، r للكفاءة r للاستقرار). وتم إجراء تحليل الانحدار

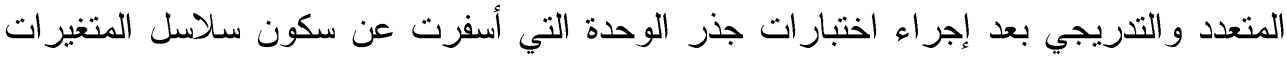

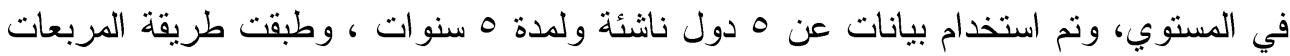

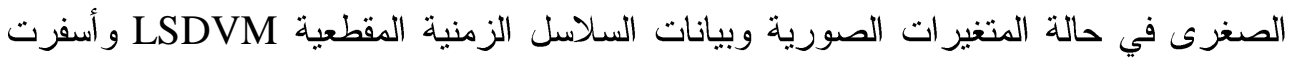
النتائج عن أهمية مؤشرات سوق الأسهم وبالتحديد المتعلقة بالحجم مقارنة بمؤشرات الكفاءة

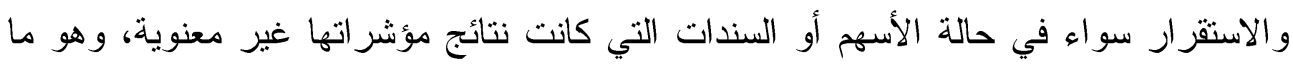
يستدعي ضرورة الاهتمام بأسواق الأسهم عامة والسندات الخاصة لتوفير الدعم للنمو الاقتصادي

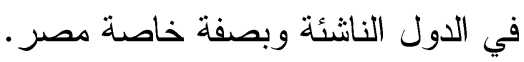




\section{Introduction}

Although a number of studies have been perform on the causal relationship between financial development and economic growth in many developing countries, the majority of these studies have depends mainly on bank development as a proxy for financial development. Specific studies between stock market indicators and growth of GDP are very scant. Previous studies on this subject have mainly used either the residual-based co integration test associated with Engle and Granger (1987) or the maximum likelihood test based on Johansen (1988) and Johansen and Juselius (1990).

Yet it is now well known that these co integration techniques may not be appropriate when the sample size is too small (see Nerayan and Smyth, 2005; Odhiambo, 2009). Some of the previous studies over relied on the cross-sectional data, which may not satisfactorily address the country specific issues.

In emerging economies, the evolution of stock market has great impact on the operation of banking institutions (Levine and Zervos, 1998). Besides that, Paudel (2005) stated that stock market, due to their liquidity, enable firms to acquire much needed capital quickly, hence facilitating capital allocation, investment and growth. Thus, domestic stock market is expected to have significant relationship with the economic growth. (Har Wai Mun, Bandar Sungai Long and others, (2008), p, 86)

Kletzer and Pardhan (1987), Beck (2002), tried to establish that financial development is much more effective in promoting economic growth in more industrialized economies than in agricultural economies. Their view has been contradicted in some other studies which argue that: countries at their early stage of development benefit more from financial sector development than their older and the identical countries. (Soumya Guha Deb, and Jaydeep Mukherjee, (2008), p, 143)

The current study attempts to investigate the relationship between stock market indicators and growth of GDP and the importance for emerging economies to reform their stock markets in order to increase their rate of economic growth. A regression analysis will be applied on a panel data consisting of 5 emerging economies across 5 years to evaluate the 
possible link between financial markets and the percentage growth of GDP in these economies.

The study uses 16 indicators as proxies of stock market development, for equity market (4 for size, 3 for efficiency, and 2 for stability), for bond market ( 2 for size, 2 for efficiency, and 2 for stability).

Few of the leaders in this subject are (Ross Levine, Thorsten Beck, and Sara Zervos), clearly as the economy grows, the financial sector needs to keep pace; Anne O. Krueger who was the first deputy managing director of IMF argues that: "Sustained and rapid growth needs to be underpinned by a broadening and deepening of the financial system, capable of serving the needs of all parts of the economy" (Kruger, 2006).

Financial sector policies in emerging economies should focus on enhancing, rather than inhibiting, the various roles of financial markets. (U1 Haque, 2002). Millner (1998) refers that financial markets promote the economic growth, but it will be necessary to consider others explanatory variables.

There are several approaches in testing for the relationship between stock markets and economic growth. One approach is to test the hypothesis on a group of countries by using either cross-section or panel data techniques (King and Levine 1993, La Porta, Lopez-de-Silanes, Sheifer and Vishny, 1997, Levine 1998) which is the approach used in this paper. Another approach is to test the hypothesis for a particular country using time series techniques (Kar and Pentecost 2000).

\section{The Importance of Panel Data:}

Panel data analysis is a method of studying a particular subject within multiple sites, periodically observed over a defined time frame. Panel analysis has enabled researchers to undertake longitudinal analyses in a wide variety of fields. Panel data analysis endows regression analysis with both a spatial and temporal dimension. Panel data sets generally include sequential blocks or cross-sections of data, within each of which resides a time series. 
There are several types of panel data analytic models. There are constant coefficients models, fixed effects models, and random effects models. (Robert Yaffee, 2003, pp, 1-2).

The combination of time series with cross-sections can enhance the quality and quantity of data in ways that would be impossible using only one of these two dimensions (Gujarati, 638). Panel data gives the researcher a large number of data points, increasing the degrees of freedom and reducing the collinearity among explanatory variables - hence improving the efficiency of econometric estimates (Cheng Hsiao, $r \cdots, p, 3$ ) .The advantages of panel data methods include the use of data from countries (when combined in a panel) for which the span of time series data is insufficient and would thus preclude the study of many hypotheses of interest. Other benefits include better power properties of the testing procedures.

\section{Emerging Market Economies:}

A country's classification as an "emerging" or "mature" market does not depend on the level of its stock market development or other economic institutions, but instead merely on whether its GNP per capita is below or above the World Bank's threshold for a "high income country" (USD 9,656 in 1998). (Randall K. Filer, Jan Hanousek and Nauro F. Campos, (2000), p, $5)$.

Emerging Economy, a term defined by Antoine Van Agtmael in the 1980s; is an economy with low-to-middle per capita income.( Economies are divided according to 2006 GNI per capita, calculated using the World Bank Atlas method, lower middle income, \$906 - \$3,595).Such countries are considered to be in a transitional period between developing and developed and represent approximately $20 \%$ of the world's economies. It is very difficult to make an exact list of all emerging economies, but the four top emerging economies are Mexico, Pakistan, Indonesia and Turkey. (According to the findings from the Grant Thornton International Business Report (IBR) in 2008)

Emerging Economies constantly seek development and reform, whether their size is large or small, resources are abundant or scarce; they are categorized as emerging. A key characteristic of Emerging Economies is an increase in both local and foreign investment. 
Emerging economy should undertake social, economic and political reforms to succeed. In their transitional reform they adopt recommended policies to replace their traditional ones that failed to produce sustainable economic growth.

\section{Financial Markets Development: (JALLOH MOHAMED, 2009, P, 11)}

Financial Markets have set up significantly and are undergoing steady innovation to improve liquidity. A financial market is a mechanism for buying and selling (i.e. trading) financial securities, commodities and other "traded" objects of value. The financial markets can be divided into different subtypes:

a) Capital markets which consist of Stock markets and Bond markets,

b) Commodity markets, which facilitate the trading of commodities.

c) Money markets, which provide short term debt financing and investment.

d) Derivatives markets, which provide instruments for the management of financial risk.

e) Futures markets, which provide standardized forward contracts for trading products at some future date.

f) Insurance markets, which facilitate the redistribution of various risks.

g) Foreign exchange markets, which facilitate the trading of foreign exchange.

Financial markets have several characteristics that play an important and positive role in emerging economies and growth. Allen and Gale (2000) and Thiel (2001) mention the proven capacity of financial markets, particularly to finance new economic sectors. Moreover "financial markets have a role in distributing and reassigning the risk of the underlying assets amongst a large number of investors, which would otherwise have no contact with the projects they end up financing.

Financial markets often enable the development of compensation models that establish a relation between operational performance and management compensation schemes. Thus, companies have an incentive to link management compensation to performance, and managers an incentive to increase capital profitability" (Afonso, Nóbrega, Freitas, Ferreira, 
Pinheiro, 2002), Sigh (1997), argues that stock markets played a basic role in external financial liberalization in developing countries. Levine and Zervos (1996) argue that a well-developed stock market may be able to offer other forms of financial services than those available from banking systems, and may, therefore, provide a different kind of motive to investment and growth.

According to IMF Senior Resident Representative in Sri Lanka; Dr. Nadeem Ul Haque, there are six basic core functions performed by the financial system (Ul Haque, 2002):

Function 1: The Mobilization of Capital. Unless financial markets are able to provide market participants with a variety of instruments of differing maturities that are traded in markets that have the depth to allow speedy exit, capital mobilization will be less than adequate.

Function 2: Risk Management and Resource Allocation. In an environment where there is uncertainty, risk sharing and insurance are the two most fundamental functions that a financial system provides. A well-functioning financial market enables multiple investors to share a project's risk allowing high-risk, highreturn investments to be undertaken. Financial markets facilitate allocation efficiency.

Function 3: Information Production, Price Discovery and Exchange of Control. Price signals contain information on quantity, scarcity and value, and thereby help agents allocate resources to their best use. The financial system, through the price discovery function, allows capital to flow toward its most productive use and bring about allocation efficiency.

Function 4: Facilitating Better Governance and Control. Financial markets promote efficient governance and control of an organized enterprise by applying external pressure and discipline on its operation.

Function 5: Efficient Clearing and Settling. An important function of the financial system is to provide an efficient way for people and businesses to make payments to each other when they wish to buy goods or services. Efficient payments and flattening 
technology allows the speedy completing of such transactions. If financial markets are to handle large transactions rapidly, clearing house and depository functions are necessary elements of the enabling environment.

Function 6: Dealing with Incentive and Agency Problems. Modern finance theory views the firm as a nexus of contracts: shareholders and or owners borrow from creditors and delegate the task of running the firm to professional managers. Financial markets endorse contractual efficiency in an environment characterized by incentive conflicts and hence lead to allocation efficiency. Financial contracts can facilitate incentive contracts for alignment of diverse interests between management, shareholders, and bondholders.

\section{5: The Importance and the major indicators of Stock markets:}

Stock markets play a critical role in mobilizing savings and in allocating them to productive investment. Moreover, strong local markets can also provide a more stable source of financing for the public and the private sectors, insulating them to some extent against volatile global capital flows.( Baboo M Nowbutsing, (2009), p, 77).

The importance of stock markets and its relation to growth should now be clear through the previous theoretical evidence. The following part, will further examine the relation between stock markets indicators and the growth of GDP in five emerging economies to provide empirical evidence.

\section{1: The major indicators of stock markets:}

The study will examine the development of only one type of stock market and its relationship with economic growth. The stock market is the major existing financial market in most emerging economies. Moreover, the choice of stock market was motivated by the study done by Levine and Zervos (1998) who found a positive and significant correlation between stock market development and long run growth.

The major indicators to the stock and bond market development used are size, efficiency, and stability. Define of these indicators and reasons behind choosing them are further described below:

5.1.1: Size Indicators: (Lin, Tzioumis, 2006) 
- Market Capitalization to GDP (\%): x1(P.A Isenmila and Akinola Adewale O, (2012), p, 66)

Market capitalization is the most commonly used indicator for equity markets. It is a measure of the value of all stocks listed on an exchange. When adjusted by Gross Domestic Product (GDP), market capitalization measures the relative size of stock markets. This is calculated by dividing the value of listed companies (market capitalization) by GDP. It gives a measure of the size of the stock market relative to the size of the economy. It is a good measure of the relative size of the stock market in the economy. (Salvatore Capasso, (2006), p, 5), the assumption behind this measure is that overall market size is positively correlated with the ability to mobilize capital and diversify risk on an economy-wide basis. (Hamid Mohtadi and Sumit Agarwal, (2001), p, 6)

- Trade Volume to GDP ratio (\%): $x 2$

Stock Traded to GDP is the total value traded divided by GDP. Value traded is the total value of shares traded during the period. Total value traded divided by GDP gives a measure of the liquidity in the market. Market liquidity measures how easily securities can be bought and sold. This indicator complements the market capitalization ratio and signals whether market size is matched by trading activity. (Salvatore Capasso, (2006), p, 5).

- Equity Mkt. Turnover Ratio (\%): x3

The equity turnover ratio, defined as the value of transactions in a year divided by end-of-year market capitalization measures market liquidity. Average market capitalization is calculated as the average of the end-ofperiod values for the current period and the previous period. Trade volume to GDP ratio and the equity market turnover ratio assist the analysis of stock market size. Both measure the capacity of a stock market in relation to trading activities, diversification, and liquidity provision function. (Salvatore Capasso, (2006), p, 5). A large but inactive market will have a large market capitalization ratio but a small turnover ratio. Turnover also complements the total value traded ratio. While the total value traded ratio captures trading relative to the size of the economy, turnover measures trading relative to the size of the stock market. A small liquid market will have a high turnover ratio but a 
small total value traded ratio. (Hamid Mohtadi and Sumit Agarwal, (2001), p, 7)

\section{- New Capital Rose to Mkt. Cap. Ratio (\%): x4}

The total value of new issues (example initial public offerings) divided by the market capitalization.

While size indicators are most popularly used, they alone should not be enough; some countries can have large but inefficient markets, while many smaller markets represent higher efficiency. Indicators like efficiency and stability enable comprehensive comparison across countries and across market dimensions.

\subsection{2: Efficiency Indicators: (Lin, Tzioumis, 2006))}

\section{- Stock return synchronicity: $x 5$}

Synchronicity captures the information content of weekly stock prices the market operates efficiently only when prices are informative about the performance of individual firms. High levels of synchronicity indicate that returns on individual stocks do not provide much firmspecific information. Thus, little useful information is made available to investors, and specific corporate information is not reflected in stock prices in an efficient way. Thus, the higher the stock return synchronicity is, the less the efficiency.

- Percentage of zero return weeks: $x 6$

The percentage of zero return weeks is calculated using the average number of zero return weeks for a country over a particular year. Higher levels of zero return weeks indicate illiquidity since investors will not trade when the transaction cost is too high or the market is too concentrated, i.e. as with the stock return synchronicity indicator, higher is worse.

- Market capitalization concentration in top-10 firms:x7

This indicator shows the share of the 10 largest firms in total market capitalization. The market capitalization concentration in top 10 firms equals: (sum of Market capitalization of top 10 firms)/ (sum of Market capitalization of all firms). The degree of market concentration is important to show how well a market really works. (Salvatore Capasso, (2006), p, 5). 


\subsection{3: Stability Indicators: (Lin, Tzioumis, 2006)}

- Equity Return Volatility: x8

Volatility is the standard deviation of the market returns. This measure is annualized to give a measure of the annual volatility. Volatility is typically higher during market declines than market booms.

- Equity Return Skew ness: x81

(This indicator will not be included in the regression model, but will be used as a mean of comparison), this indicator is defined as the skew ness of market index return. A market with a more negatively skewed distribution of stock returns is likely to deliver large negative returns, and may be prone to less stability.

\section{2.: Bond Market Indicators}

Given the increased role of bond financing overtime, information on this form of financing has become important, especially for countries that are relatively new participants as emerging market economies.

\subsection{1: Size Indicators: (Lin, Tzioumis, 2006)}

- Private sector bond to GDP ratio:x9

Private sector bond markets substitute the banking sector in providing medium and long-term finance, primarily for infrastructure projects. This indicator shows the relative distribution of private sector bonds to GDP, and it equals: Total amount of outstanding domestic debt securities by private domestic entities divided by GDP.

- Public sector bond to GDP ratio: $\mathbf{x 1 0}$

This indicator shows the relative distribution of public sector bonds to GDP, it equals: Total amount of outstanding domestic debt securities by public domestic entities divided by GDP.

\section{- International bond to GDP ratio: $x 11$}

The ratio of international bonds to GDP reflects a country's ability to raise capital globally. This indicator shows the ratio of international bond to GDP, it is equal to: Total amount of international debt securities divided by the GDP.

\subsection{2: Efficiency Indicators: (Lin, Tzioumis, 2006)}

To measure the efficiency of bond markets, the focus will be brought on the liquidity of markets as reflected by: 
- Turnover ratio (private sector): $\mathbf{x 1 2}$

This indicator is defined as the value of private sector bonds at time $\mathrm{t}$ divided by the average of total value of debt at time $t$ and time ( $t-1)$.

- Turnover ratio (public sector): $x 13$

This indicator is defined as the value of public bonds traded at time $t$ divided by the average of total value of debt at time $t$ and time ( $t-1)$.

\subsection{3: Stability Indicators: (Lin, Tzioumis, 2006)}

Due to the scarcity of high-frequency data on corporate bonds, the focus for this section is mainly on government bonds.

- Volatility of government bonds: x14

Volatility is the commonly used indicator of stability. It is defined as the annualized standard deviation of daily returns on government Bonds.

\section{- Skew ness of government bonds: x14.1}

(This indicator will not be included in the regression model, but will be used as a mean of comparison) Skew-ness measures the probability of large negative losses associated with countries' sovereign bonds. It is defined as the skew ness of daily returns on government bonds.

\section{6: Methodology:}

Using panel data method and Fixed Effects Model with Country Specific Effects, the study will test the role of stock market through 16 indicators represent equity market ( 4 for size market indicators, 3 for efficiency market indicators, 2 for stability market indicators), and bond market ( 3 for size market indicators, 2 for efficiency and 2 for stability market indicators).

\section{1: Data, Model and Estimation Technique: \\ 6. 1.1: Sources of Data:}

The data used in this study is based on a panel data set over the period 2001-2005 for five emerging countries (India, Malaysia, Turkey, Brazil and Egypt), Table 1 and 2 shows the basic data which are used in estimate the models. The data is sourced from The World Bank Group, All Rights Reserved. Terms and Conditions, Privacy Policy, 2007 for the equity market indicators and the bond market indicators and those of the growth rate of 
gross domestic product. The period chosen for the study cover the sixteen indicators for the five emerging countries exception some years. Due to the short time series (because of the unavailability of data) a dummy variable will be used. This dummy variable will act as a link between the countries and years and through that extending the observations to 25 observations (5years $* 5$ countries).

\subsection{2: The Model and Estimation Technique (Method of Analysis):}

The model considered below for empirical analysis on the role of equity market and bond market in growth of GDP through the size market indicators, efficiency market indicators, and stability market indicators in Fixed Effects Model. Where the model in case of dummy variables called: Least Squares with Dummy Variables Model (LSDVM).

The relationship between stock market (which is divided to equity market: $\mathrm{x} 1, \mathrm{x} 2, \mathrm{x} 3$ and $\mathrm{x} 4$ for size indicators, $\mathrm{x} 5, \mathrm{x} 6, \mathrm{x} 7$ for efficiency, $\mathrm{x} 8$, $\mathrm{x} 8.1$ for stability, and bond market: $\mathrm{x} 9, \mathrm{x} 10, \mathrm{x} 11$ for size, $\mathrm{x} 12, \mathrm{x} 13$ for efficiency and $\mathrm{x} 14, \mathrm{x} 14.1$ for stability), and the economic growth which is represented by the growth of growth of gross national product (Yi) using $i$ and $t$ to denote country and time period (year). Where if there are differences between countries in the study in the Least Squares with Dummy Variables Model, then the estimators obtained by Ordinary Least Squares will be biased, therefor according to econometric literature the dummy variables must be used to reflect these differences between countries through Fixed Effects Model with Country Specific Effects, (Baltagi, 1995; Hsiao, 1986).The number of estimators equal the number of the dummy variables which is equal the numbers of countries and the numbers of coefficients for the explanatory variables. The model is specified as : (Narayana, 2001: pp, 6-7):

$$
\begin{gathered}
Y_{i t}=\alpha \delta_{1 i t}+\alpha_{2} \delta_{2 i t}+\ldots . .+X^{\prime}{ }_{i t} \beta_{i t}+\varepsilon_{i t} \\
i=1,2, \ldots \ldots, n \\
t=1,2, \ldots ., T
\end{gathered}
$$

The model dose not has intercept to avoid the dummy variables for countries and the intercept. The model specified for the study was estimated using the stepwise least squares regression method. 
The Role of Stock Markets in Economic Growth

Evidence From Emerging Economies, A Panel Data Analysis Dr. Abdelmohsen Mostafa Abdallah

Table:1

Equity Market Indicators

\begin{tabular}{|c|c|c|c|c|c|c|c|c|c|c|c|}
\hline \multirow[t]{2}{*}{ country } & \multirow[t]{2}{*}{ year } & \multirow{2}{*}{$\begin{array}{c}\text { GDP } \\
\% \\
\text { Growth } \\
\end{array}$} & \multicolumn{4}{|c|}{$\begin{array}{c}\text { Size } \\
\text { Indicators }\end{array}$} & \multicolumn{3}{|c|}{$\begin{array}{l}\text { Efficiency } \\
\text { Indicators }\end{array}$} & \multicolumn{2}{|c|}{$\begin{array}{c}\text { Stability } \\
\text { Indicators } \\
\end{array}$} \\
\hline & & & $\mathrm{X} 1$ & $\mathrm{X} 2$ & $\mathrm{X} 3$ & $\mathrm{X} 4$ & X5 & X6 & $\mathrm{X} 7$ & $\mathrm{X} 8$ & X8.1 \\
\hline \multirow{5}{*}{ India } & 2001 & 5.21 & 22.987 & 2.02 & 191.4 & 0.41 & 0.28 & 7.54 & 44.53 & 30.76 & -0.157 \\
\hline & 2002 & 3.73 & 25.739 & 38.73 & 225.82 & 0.31 & 0.25 & 7.54 & 48.9 & 28.2 & -0.142 \\
\hline & 2003 & 8.39 & 46.466 & 47.42 & 138.54 & 0.34 & 0.23 & 3.7 & 40.98 & 22.2 & -0.157 \\
\hline & 2004 & 8.32 & 56.058 & 54.79 & 113.68 & 2.15 & 0.35 & 0 & 40.06 & 22.02 & -0.400 \\
\hline & 2005 & 9.23 & 71.067 & 56.42 & 93.61 & 2.32 & 0.31 & 0.65 & 44.37 & 21.11 & -0.406 \\
\hline \multirow{5}{*}{ Malaysia } & 2001 & 0.32 & 135.23 & 23.6 & 17.5 & 0.37 & 0.47 & 18.85 & 33.74 & 22.96 & 0.704 \\
\hline & 2002 & 4.15 & 130.3 & 29.03 & 17.46 & 1.44 & 0.28 & 22.62 & 36.14 & 18.61 & 0.728 \\
\hline & 2003 & 5.69 & 162.31 & 48.33 & 34.31 & 0.57 & 0.4 & 18.49 & 33.6 & 15.28 & 0.754 \\
\hline & 2004 & 7.23 & 161.33 & 50.84 & 33.42 & 1.01 & 0.18 & 22.62 & 36.52 & 11.41 & 0.774 \\
\hline & 2005 & 5.16 & 144.01 & 38.33 & 26.61 & 1.05 & 0.18 & 6.73 & 40.88 & 10.19 & 0.721 \\
\hline \multirow{5}{*}{ Turkey } & 2001 & -7.49 & 32.84 & 53.66 & 161.5 & $\mathbf{0}$ & 0.51 & 18.85 & 58.21 & 56.56 & 0.012 \\
\hline & 2002 & 7.94 & 18.49 & 38.43 & 163.43 & 0.51 & 0.36 & 22.62 & 54.29 & 53.78 & 0.053 \\
\hline & 2003 & 5.79 & 28.45 & 41.44 & 192.39 & 0.1 & 0.35 & 18.49 & 54.61 & 48.23 & 0.026 \\
\hline & 2004 & 8.93 & 32.56 & 48.83 & 176.9 & 1.47 & 0.26 & 22.62 & 52.63 & 36.98 & 0.027 \\
\hline & 2005 & 7.38 & 35.95 & 55.4 & 154.12 & 1.66 & 0.3 & 6.73 & 52.16 & 30.9 & -0.002 \\
\hline \multirow{5}{*}{ Brazil } & 2001 & 1.31 & 36.58 & 12.8 & 34.5 & 0.85 & 0.29 & 22.62 & 70.2 & 37.39 & 0.738 \\
\hline & 2002 & 2.66 & 26.91 & 10.46 & 34.95 & 1.6 & 0.23 & 33.94 & 67.68 & $\mathbf{3 2 . 3 7}$ & 0.696 \\
\hline & 2003 & 1.15 & 46.38 & 11.95 & 32.43 & 0.34 & 0.17 & 25.89 & 66.67 & 29.9 & 0.689 \\
\hline & 2004 & 5.71 & 54.62 & 15.47 & $\mathbf{3 3 . 1 3}$ & 0.93 & 0.19 & 22.62 & 63.49 & 28.05 & 0.661 \\
\hline & 2005 & 2.95 & 51 & 19.42 & 38.08 & 1.1 & 0.17 & 48.86 & 78.59 & 25.71 & 0.585 \\
\hline \multirow{5}{*}{ Egypt } & 2001 & 3.54 & 24.575 & 3.957 & 14.200 & & 0.323 & 5.769 & 15.482 & 27.709 & 0.417 \\
\hline & 2002 & 2.37 & 29.047 & 2.847 & 16.130 & & 0.140 & 5.769 & 13.233 & 26.840 & 0.399 \\
\hline & 2003 & 3.89 & 32.844 & 3.977 & 13.730 & & 0.203 & 5.769 & 23.457 & 25.201 & 0.747 \\
\hline & 2004 & 4.09 & 51.254 & 7.463 & 17.101 & 0.465 & 0.189 & 5.769 & 38.600 & 22.841 & 0.654 \\
\hline & 2005 & 4.47 & 66.372 & 28.423 & 42.820 & 2.022 & 0.355 & 11.186 & 48.860 & 11.606 & 0.646 \\
\hline
\end{tabular}

Source of Data: The World Bank Group, All Rights Reserved. Terms and Conditions. Privacy Policy. 2007.

X1: Market Capitalization to GDP ratio(\%).

X2: Trade Volume to GDP ratio (\%)

X3: Equity Mkt. Turnover Ratio (\%)

X4: New Capital Raised to Mkt. Cap. Ratio (\%)

X5: Stock return synchronicity

X6: Percentage of zero return weeks

X7: Market capitalization concentration in top-10 firms

X8: Equity Return Volatility

X8.1: Equity Return Skew-ness 
Table 2

Bond Market Indicators

\begin{tabular}{|c|c|c|c|c|c|c|c|c|c|}
\hline \multirow{2}{*}{ country } & \multirow{2}{*}{ year } & \multirow{2}{*}{$\begin{array}{c}\text { GDP } \\
\% \\
\text { Growth }\end{array}$} & \multicolumn{3}{|c|}{ Size Indicators } & \multicolumn{2}{|c|}{$\begin{array}{l}\text { Efficiency } \\
\text { Indicators }\end{array}$} & \multicolumn{2}{|c|}{$\begin{array}{c}\text { Stability } \\
\text { Indicators }\end{array}$} \\
\hline & & & X9 & X10 & X11 & X12 & X13 & X14 & X14.1 \\
\hline \multirow{5}{*}{ India } & 2001 & 5.21 & 0.41 & 24.98 & 0.87 & . & . & - & - \\
\hline & 2002 & 3.73 & 0.41 & 27.7 & 0.73 & 86.03 & 122.78 & - & - \\
\hline & 2003 & 8.39 & 0.4 & 29.01 & 0.57 & 36.14 & 130.8 & - & - \\
\hline & 2004 & 8.32 & 0.5 & 31.02 & 0.71 & 44.66 & 69.31 & - & - \\
\hline & 2005 & 9.23 & 0.97 & 32.96 & 1.1 & 27.61 & 40.49 & - & - \\
\hline \multirow{5}{*}{ Malaysia } & 2001 & 0.32 & 55.11 & 34.22 & 19.12 & 22.43 & - & 4.81 & 1.905 \\
\hline & 2002 & 4.15 & 53.22 & 34.77 & 21.55 & 23.02 & - & 8.92 & -0.209 \\
\hline & 2003 & 5.69 & 52.16 & 35.73 & 22.72 & 21.03 & - & 7.87 & 0.833 \\
\hline & 2004 & 7.23 & 51.44 & 37.08 & 22.29 & 20.14 & - & 7.72 & -0.028 \\
\hline & 2005 & 5.16 & 52.36 & 38.3 & 22.4 & 16.08 & - & - & - \\
\hline \multirow{5}{*}{ Turkey } & 2001 & -7.49 & - & 48.6 & 15.52 & - & 144.65 & 19.64 & -0.726 \\
\hline & 2002 & 7.94 & - & 48.79 & 12.55 & - & 156.97 & 12.37 & -0.483 \\
\hline & 2003 & 5.79 & - & 49.4 & 10.61 & - & 206.61 & 15.44 & -1.578 \\
\hline & 2004 & 8.93 & - & 51.22 & 9.52 & - & 302.8 & 9.81 & -2.427 \\
\hline & 2005 & 7.38 & - & 49.24 & 9.24 & - & 329.14 & 5.1 & -0.726 \\
\hline \multirow{5}{*}{ Brazil } & 2001 & 1.31 & 9.82 & 50.23 & 16.91 & 11.73 & - & 15.69 & 0.559 \\
\hline & 2002 & 2.66 & 9.84 & 46.83 & 18.77 & 21.88 & - & 32.13 & -0.776 \\
\hline & 2003 & 1.15 & 9.48 & 41.72 & 19.36 & 21.88 & - & 14.56 & -0.350 \\
\hline & 2004 & 5.71 & 10.67 & 45.01 & 17.69 & 8.61 & - & 14.14 & -0.420 \\
\hline & 2005 & 2.95 & 12.01 & 44.7 & 13.65 & 7.92 & 1.01 & 7.073 & -0.872 \\
\hline \multirow{5}{*}{ Egypt } & 2001 & 3.54 & - & - & 0.873 & - & - & 18.638 & -6.710 \\
\hline & 2002 & 2.37 & - & - & 1.832 & - & - & 4.930 & -0.067 \\
\hline & 2003 & 3.89 & - & - & 1.944 & - & - & 5.092 & 1.219 \\
\hline & 2004 & 4.09 & - & - & 1.985 & - & - & 4.774 & 0.084 \\
\hline & 2005 & 4.47 & - & - & 3.252 & 2.590 & 25.680 & 5.364 & 1.373 \\
\hline
\end{tabular}

Source of Data: The World Bank Group, All Rights Reserved. Terms and Conditions. Privacy Policy. 2007. X9: Private Sector bond to GDP ratio.

X10: Public sector bond to GDP ratio

X11: International bond to GDP ratio

X12: Turnover ratio (private sector)

X13: Turnover ratio (public sector)

X14: Volatility of government bonds

X14.1: Skew-ness of government bonds 
The following is an example of the use of these dummy variables with the stock market size indictors:

\subsection{3: An example of Equity Market Size Indicators with Dummy Variable:}

$\mathrm{X}_{1}$ : will account for the 1st indicator: Market Capitalization to GDP\%

$\mathrm{X}_{2}$ : Trade Volume to GDP Ratio\%

$\mathrm{X}_{3}$ : Equity Mkt. Turnover Ratio\%

$\mathrm{X}_{4}$ : New Capital Rose to Mkt. Cap Ratio\%

$d_{1} x_{1}$ will account for India $-d_{2} x_{1}$ for Malaysia $-d_{3} x_{1}$ for turkey $-d_{4} x_{1}$ for Brazil and $d_{5} x_{1}$ for Egypt.

$\begin{array}{ccccc}\mathrm{d}_{1} \mathrm{x}_{2} & \mathrm{~d}_{2} \mathrm{x}_{2} & \mathrm{~d}_{3} \mathrm{x}_{2} & \mathrm{~d}_{4} \mathrm{x}_{2} & \mathrm{~d}_{5} \mathrm{x}_{2} \\ \mathrm{~d}_{1} \mathrm{x}_{3} & \mathrm{~d}_{2} \mathrm{x}_{3} & \mathrm{~d}_{3} \mathrm{x}_{3} & \mathrm{~d}_{4} \mathrm{x}_{3} & \mathrm{~d}_{5} \mathrm{x}_{3} \\ \mathrm{~d}_{1} \mathrm{x}_{4} & \mathrm{~d}_{2} \mathrm{x}_{4} & \mathrm{~d}_{3} \mathrm{x}_{4} & \mathrm{~d}_{4} \mathrm{x}_{4} & \mathrm{~d}_{5} \mathrm{x}_{4}\end{array}$

And so on for other $\mathrm{x}$ 's.

$\mathrm{d} 1, \mathrm{~d} 2, \mathrm{~d} 3, \mathrm{~d} 4$ and $\mathrm{d} 5$ are the Dummy variables where:

$\mathrm{d} 1:=1$ in case of India, while others $(\mathrm{d} 2, \mathrm{~d} 3, \mathrm{~d} 4$ and $\mathrm{d} 5$ all $=0)$

$\mathrm{d} 2:=1$ in case of Malaysia others $(\mathrm{d} 1, \mathrm{~d} 3, \mathrm{~d} 4$ and $\mathrm{d} 5$ all $=0)$

$\mathrm{d} 3:=1$ in case of Turkey, while others $(\mathrm{d} 1, \mathrm{~d} 2, \mathrm{~d} 4$ and $\mathrm{d} 5$ all $=0)$

$\mathrm{d} 4:=1$ in case of Brazil, while others $(\mathrm{d} 1, \mathrm{~d} 2, \mathrm{~d} 3$ and $\mathrm{d} 5$ all $=0$ )

$\mathrm{d} 5:=1$ in case of Egypt, while others (d1, d2, d3 and d4 all $=0$ )

This will be applied also to all other indicators. Each category of indicators (size, efficiency, stability) will be examined through 4 different forms, linear form, log - $\log$ form, semi-log form and exponential form (natural $\log$ for Y).

\section{7: Empirical results and Findings:}

The analysis begins with testing for unit roots in the data. Table: 3 assemble the results from the ADF and KPSS testing procedures.

\section{1: Unit Root Test for the equity market indicators using ADF, KPSS:}

As the results show, all variables appear stationary in levels and in first differences according to KPSS test, and ADF test for some variables, for these results, the Least Squares with Dummy Variables Model method using to estimates the Fixed Effects Model with Country Specific Effects. However, the variables proved stationary in level. The models specified for the study was estimated using the least squares regression enter method and the stepwise least squares regression method. The findings of the study from the analysis done could be summarized as shown below. 
Table: 3 Unit Root Test for the equity and bond market indicators:

\begin{tabular}{|c|c|c|c|c|c|}
\hline \multirow{2}{*}{\multicolumn{2}{|c|}{ Variable }} & \multicolumn{2}{|c|}{ Level } & \multicolumn{2}{|c|}{ First Difference } \\
\hline & & $\mathrm{ADF}$ & KPSS & ADF & KPSS \\
\hline \multicolumn{2}{|c|}{$\mathrm{Y}$} & $-4.718 * * *$ & $0.1998 * * *$ & $-6.059 * * *$ & $0.228 * * *$ \\
\hline \multicolumn{2}{|c|}{$\mathrm{X} 1$} & -1.65 & $0.1994 * * *$ & $-3.575 * *$ & $0.126 * * *$ \\
\hline \multicolumn{2}{|c|}{$\mathrm{X} 2$} & -2.199 & $0.431 * *$ & $-5.417 * * *$ & 0.307 *** \\
\hline \multicolumn{2}{|c|}{$\mathrm{X} 3$} & -1.867 & $0.268 * * *$ & $-4.434 * * *$ & $0.91 * * *$ \\
\hline \multicolumn{2}{|c|}{$\mathrm{X} 4$} & $-3.96 * * *$ & $0.058 * * *$ & $-5.373 * * *$ & $0.473 *$ \\
\hline \multicolumn{2}{|c|}{$\mathrm{X} 5$} & -1.65 & $0.413 * *$ & $-8.028 * * *$ & $0.201 * * *$ \\
\hline \multicolumn{2}{|c|}{ X6 } & $-3.217 * *$ & $0.242 * * *$ & $-6.755 * * *$ & $0.5^{*}$ \\
\hline \multicolumn{2}{|c|}{$\mathrm{X} 7$} & $-2.73 *$ & $0.13 * * *$ & $-5.19 * * *$ & $0.103 * * *$ \\
\hline \multicolumn{2}{|c|}{$\mathrm{X} 8$} & -2.3 & $0.143 * * *$ & $-4.568 * * *$ & $0.087 * * *$ \\
\hline \multicolumn{2}{|c|}{$\mathrm{X} 8.1$} & -0.524 & $0.342 * * *$ & $-4.796 * * *$ & $0.061 * * *$ \\
\hline \multicolumn{2}{|c|}{$\mathrm{X9}$} & -0.919 & $0.143^{* * *}$ & $-3.404 * *$ & $0.163 * * *$ \\
\hline \multicolumn{2}{|c|}{$\mathrm{X} 10$} & -1.827 & $0.502 *$ & $-3.912 * * *$ & $0.295 * * *$ \\
\hline \multicolumn{2}{|c|}{$\mathrm{X} 11$} & -2.191 & $0.141 * * *$ & $-3.668 * *$ & $0.193 * * *$ \\
\hline \multicolumn{2}{|c|}{$\mathrm{X} 12$} & -1.63 & $0.599 * *$ & $-4.49 * *$ & $0.266^{* * * *}$ \\
\hline \multicolumn{2}{|c|}{$\mathrm{X} 13$} & 1.348 & $0.11 * * *$ & - & $0.295 * * *$ \\
\hline \multicolumn{2}{|c|}{$\mathrm{X} 14$} & $-3.073 *$ & $0.153 * * *$ & -5.391 & $0.334 * * *$ \\
\hline \multicolumn{2}{|c|}{$\mathrm{X} 14.1$} & $-3.555^{* *}$ & 0.13 *** & $-5.341 * * *$ & $0.48^{*}$ \\
\hline \multirow{3}{*}{$\begin{array}{l}\text { Critical } \\
\text { values }\end{array}$} & $1 \%$ & -3.573 & 0.739 & -3.381 & 0.739 \\
\hline & $5 \%$ & -2.998 & 0.463 & -3.029 & 0.463 \\
\hline & $10 \%$ & -2.639 & 0.347 & -2.655 & 0.347 \\
\hline
\end{tabular}

Source: Computed according data in table 1, ***: significance, at all levels 1\%, 5\%and $10 \%$. **: significance, at all levels $1 \%$ and $5 \%$.

\section{2: The least squares regression (enter) method results for equity market (Size Indicators):}

In table 4: From the results, using the least squares regression enter method. The implication is that the equity market size indicators are useful for explaining the growth rate of GDP that has occurred especially in Turkey where the results of x1((Market capitalization to GDP \%) and X4 (New Capital raised to market) are acceptable economically, and the T value is significant for each indicator and the $\mathrm{F}$ value is significant at less than 1 percent level, beside that a highly significant coefficient of determination (99.8 percent) for the full relationship.

In India the results insignificant economically and statistically, but the result shows that the $\mathrm{x} 4$ (New Capital raised to market) only is acceptable economically and significant for Malaysia. For Brazil, the results of x1and $\mathrm{x} 4$ are acceptable economically and significant but $\mathrm{x} 2$ (Trade volume to GDP ratio) is not acceptable econometrically although it is significant. For Egypt 
X2 (Trade volume to GDP ratio) only acceptable according to the economic standards but it is significant at $10 \%$ level.

The Durbin Watson (DW) statistic Of 2.616 indicates that there is no problem of serial or autocorrelation in the regression model.

\section{Table 4 results, using the least squares regression enter method:}

\begin{tabular}{|c|c|c|c|c|c|}
\hline \multirow{2}{*}{ Model } & \multicolumn{2}{|c|}{$\begin{array}{c}\text { Unstandardized } \\
\text { Coefficients }\end{array}$} & $\begin{array}{c}\text { Standardized } \\
\text { Coefficients }\end{array}$ & \multirow{2}{*}{$\mathrm{t}$} & \multirow{2}{*}{ Sig. } \\
\cline { 2 - 4 } & $\mathrm{B}$ & Std. Error & Beta & & \\
\hline (Constant) & 123.870 & 20.911 & & 5.924 & .010 \\
\hline $\mathrm{d} 1 \times 1$ & $-.003-$ & .071 & $-.019-$ & -.047 & .966 \\
\hline $\mathrm{d} 1 \times 2$ & .008 & .024 & .043 & .340 & .756 \\
\hline $\mathrm{d} 1 \times 3$ & $-.054-$ & .018 & $-1.005-$ & -2.996 & .058 \\
\hline $\mathrm{d} 1 \times 4$ & $-.790-$ & .484 & $-.138-$ & -1.632 & .201 \\
\hline $\mathrm{d} 2 \times 2$ & .103 & .226 & .475 & .457 & .679 \\
\hline $\mathrm{d} 2 \times 3$ & .133 & .329 & .417 & .405 & .713 \\
\hline $\mathrm{d} 2 \times 4$ & 3.086 & 1.291 & .350 & 2.390 & .097 \\
\hline $\mathrm{d} 3 \times 1$ & 1.812 & .350 & 6.365 & 5.185 & .014 \\
\hline $\mathrm{d} 3 \times 2$ & $-2.539-$ & .360 & $-14.106-$ & -7.043 & .006 \\
\hline $\mathrm{d} 3 \times 3$ & $-.338-$ & .082 & $-6.654-$ & -4.145 & .026 \\
\hline $\mathrm{d} 3 \times 4$ & 6.722 & .520 & .835 & 12.920 & .001 \\
\hline $\mathrm{d} 4 \times 1$ & .310 & .049 & 1.595 & 6.312 & .008 \\
\hline $\mathrm{d} 4 \times 2$ & $-.505-$ & .133 & $-.843-$ & -3.789 & .032 \\
\hline $\mathrm{d} 4 \times 4$ & 5.251 & .819 & .646 & 6.413 & .008 \\
\hline $\mathrm{d} 5 \times 1$ & $-.002-$ & .033 & $-.011-$ & -.064 & .953 \\
\hline $\mathrm{d} 5 \times 2$ & .470 & .208 & .775 & 2.256 & .109 \\
\hline $\mathrm{d} 5 \times 3$ & $-.369-$ & .160 & $-1.032-$ & -2.310 & .104 \\
\hline
\end{tabular}

\section{3: The stepwise least squares regression method: for equity market (Size Indicators):}

Table 5 reports the results of the regressions using the stepwise least squares regression method for the four explanatory variables which are represent the equity market size indicators (x1, x2, x3, and $x 4)$. The implication is that the equity market size indicators are useful for explaining the growth rate of GDP that has occurred especially in Turkey between 2001-2005, where the results is agree economically, the impact of $\mathrm{x} 1, \mathrm{x} 2$, $\mathrm{x} 3, \mathrm{x} 4$ on GDP is positive, The $\mathrm{T}$ value is significant for each indicator and the $\mathrm{F}$ value is significant at less than 1 percent level for Turkey, but $\mathrm{x} 1$ only is important explanatory variable for India. In case of Brazil and Egypt all 
results are rejecting economically and statistically although there is no serial correlation problem according to the Durbin Watson (DW) statistic (2.765).

\section{Table 5 The stepwise least squares regression method:}

\begin{tabular}{|c|c|c|c|c|c|}
\hline \multirow[b]{2}{*}{ Model } & \multicolumn{2}{|c|}{ Unstandardized Coefficients } & \multirow{2}{*}{$\frac{\text { Standardized Coefficients }}{\text { Beta }}$} & \multirow{2}{*}{$\mathrm{t}$} & \multirow{2}{*}{ Sig. } \\
\hline & B & Std. Error & & & \\
\hline (Constant) & 3.805 & .716 & & 5.314 & .000 \\
\hline $\mathrm{d} 1 \mathrm{x} 1$ & .076 & .033 & .432 & 2.295 & .031 \\
\hline (Constant) & 3.173 & .691 & & 4.596 & .000 \\
\hline $\mathrm{d} 1 \mathrm{x} 1$ & .089 & .030 & .500 & 2.919 & .008 \\
\hline $\mathrm{d} 3 \mathrm{x} 4$ & 3.498 & 1.380 & .434 & 2.534 & .019 \\
\hline (Constant) & 3.748 & .657 & & 5.704 & .000 \\
\hline $\mathrm{d} 1 \mathrm{x} 1$ & .078 & .027 & .438 & 2.822 & .010 \\
\hline $\mathrm{d} 3 \mathrm{x} 4$ & 6.948 & 1.829 & .863 & 3.798 & .001 \\
\hline $\mathrm{d} 3 \mathrm{x} 1$ & $-.167-$ & .065 & -.588 & $-2.555-$ & .018 \\
\hline (Constant) & 3.543 & .510 & & 6.949 & .000 \\
\hline $\mathrm{d} 1 \mathrm{x} 1$ & .081 & .021 & .460 & 3.838 & .001 \\
\hline $\mathrm{d} 3 \mathrm{x} 4$ & 8.723 & 1.483 & 1.083 & 5.881 & .000 \\
\hline $\mathrm{d} 3 \mathrm{x} 1$ & $-.739-$ & .155 & $-2.597-$ & $-4.770-$ & .000 \\
\hline $\mathrm{d} 3 \times 3$ & .097 & .025 & 1.911 & 3.904 & .001 \\
\hline (Constant) & 3.584 & .460 & & 7.792 & .000 \\
\hline $\mathrm{d} 1 \mathrm{x} 1$ & .081 & .019 & .456 & 4.215 & .000 \\
\hline $\mathrm{d} 3 \mathrm{x} 4$ & 8.932 & 1.340 & 1.109 & 6.664 & .000 \\
\hline $\mathrm{d} 3 \mathrm{x} 1$ & $-.152-$ & .285 & $-.535-$ & $-.535-$ & .599 \\
\hline $\mathrm{d} 3 \times 3$ & .130 & .026 & 2.548 & 4.930 & .000 \\
\hline $\mathrm{d} 3 \mathrm{x} 2$ & $-.489-$ & .206 & $-2.716-$ & $-2.368-$ & .029 \\
\hline (Constant) & 3.591 & .452 & & 7.952 & .000 \\
\hline $\mathrm{d} 1 \mathrm{x} 1$ & .081 & .019 & .455 & 4.286 & .000 \\
\hline $\mathrm{d} 3 \mathrm{x} 4$ & 8.790 & 1.290 & 1.091 & 6.813 & .000 \\
\hline $\mathrm{d} 3 \times 3$ & .130 & .026 & 2.564 & 5.060 & .000 \\
\hline $\mathrm{d} 3 \times 2$ & $-.585-$ & .100 & $-3.250-$ & -5.878 & .000 \\
\hline (Constant) & 2.962 & .484 & & 6.124 & .000 \\
\hline $\mathrm{d} 1 \mathrm{x} 1$ & .093 & .018 & .523 & 5.251 & .000 \\
\hline $\mathrm{d} 3 \mathrm{x} 4$ & 8.792 & 1.161 & 1.092 & 7.576 & .000 \\
\hline $\mathrm{d} 3 \times 3$ & .133 & .023 & 2.613 & 5.728 & .000 \\
\hline $\mathrm{d} 3 \mathrm{x} 2$ & $-.581-$ & .090 & $-3.226-$ & $-6.486-$ & .000 \\
\hline $\mathrm{d} 2 \times 2$ & .052 & .022 & .239 & 2.392 & .027 \\
\hline (Constant) & 3.176 & .418 & & 7.605 & .000 \\
\hline $\mathrm{d} 1 \mathrm{x} 1$ & .089 & .015 & .500 & 5.877 & .000 \\
\hline $\mathrm{d} 3 \mathrm{x} 4$ & 8.792 & .986 & 1.092 & 8.915 & .000 \\
\hline $\mathrm{d} 3 \times 3$ & .132 & .020 & 2.597 & 6.697 & .000 \\
\hline $\mathrm{d} 3 \times 2$ & $-.582-$ & .076 & $-3.234-$ & $-7.652-$ & .000 \\
\hline $\mathrm{d} 2 \times 2$ & .285 & .083 & 1.310 & 3.438 & .003 \\
\hline $\mathrm{d} 2 \mathrm{x} 1$ & $-.065-$ & .023 & $-1.106-$ & $-2.883-$ & .010 \\
\hline
\end{tabular}




\section{4: The least squares regression (enter) method results for equity market (Efficiency Indicators):}

According the least squares regressions enter method the results clearly show that the equity market efficiency indicators (x5, x6 and x7) are not consistent with economic theory, where all the signs of all regression coefficient are negative, and insignificant according to t test for each one, beside that $\mathrm{f}$ test refers to that the regression is insignificant although it is explaining $89.6 \%$ of the growth rate of GDP changing that has occurred in all countries in the study through the period 2001-2005 through the value of $\mathrm{R}^{2}$. Exception of These results $\mathrm{x} 5$ for India in $\log -\log$ form according to economic theory. The conflict in these results refers to that there are multicollinearety econometric problem although there are not serial or Autocorrelation according to Durbin- Watson statistics.

\section{5: The results of equity market stability indicators:}

The results clearly show that the Equity Return Skew-ness (x8.1) is the only equity market stability indicator for Turkey which is accepted economically (the sign is positive), and significant according t test. The Ftest is significant, $\mathrm{R}^{2}$ is 0.907 . This conflict of results refers to presence of multicollinearity problem so the stepwise regression must be made to delete these variables which are responsible for the problem as follow.

\section{6: The stepwise least squares regression method: for equity market (Stability Indicators):}

The check of the adequacy of the estimated equations in the alternative method stepwise least squares regression method show that the only equity market stability indicator (the Equity Return Skew-ness (x8.1) for India) is accepted economically ( positive sign), and significant according $\mathrm{t}$ test, and the $\mathrm{f}$ test for the full regression is significant, furthermore $\mathrm{R}^{2}$ is interpret $16.8 \%$ in the change in GDP which is occurred in India in this period, beside that there is no autocorrelation problem according to D-W statistics.

\section{7: The results of Bond market size indicators:}

Results are accepted economically for estimators of all countries for x9 (Private Sector bond to GDP ratio) where their estimators are positive, $\mathrm{d} 3 \mathrm{x} 9$ which is the indicator in relation with Turkey was deleted from the analysis due to missing unavailable data. For x10 (Public sector bond to 
GDP ratio), the results with Egypt was deleted from the analysis due to missing unavailable data, the results for Malaysia and Brazil accepted economically where there regression coefficients are positive, but rejected for India and Turkey where the sin of the regression coefficient are negative. In case of $x 11$ (International bond to GDP ratio), the results accepted economically for Malaysia, Brazil and Egypt (positive sign), and rejected for India and Turkey for the negative sign. Statistically all regression coefficients exception Malaysia insignificant according to $\mathrm{T}$ test and $\mathrm{F}$ test, and $\mathrm{R}^{2}$ refers to that $78.7 \%$ from the changes in GDP are interpreted by the bond market stability indicators. D-W statistics show that there are not Autocorrelation from one side, but the conflict between results refers to multicollinearity, for these results stepwise regression must be made but there are not any improvements of the results.

\section{8: The results of Bond market Efficiency indicators:}

Results are rejected economically for all estimators where the values are negative. However $\mathrm{d} 2 \times 13$ Turnover ratio (private sector) which is the indicator with relation to Malaysia, $\mathrm{d} 3 \mathrm{x} 3$, Turnover ratio (public sector) for Turkey, and d5x12, d5x13 for Egypt, has been deleted due to missing data. According to Statistics the regression coefficients exception d1 x13 for India significant according to t test except. Although the value of $\mathrm{R}^{2}$ is high 0.992 but $f$ test show that the regression relationship is insignificant, and $\mathrm{D}: \mathrm{W}$ statistics refers to that there are autocorrelation problem, these conflict in the results show clearly that there are multicollinearity.

\section{Table:6 Results of Bond market Efficiency indicators}

\begin{tabular}{|c|c|c|c|c|c|}
\hline \multirow{2}{*}{ Model } & \multicolumn{2}{|c|}{$\begin{array}{c}\text { Unstandardized } \\
\text { Coefficients }\end{array}$} & $\begin{array}{c}\text { Standardized } \\
\text { Coefficients }\end{array}$ & \multirow{2}{*}{$\mathrm{t}$} & \multirow{2}{*}{ Sig. } \\
\cline { 2 - 4 } & $\mathrm{B}$ & Std. Error & Beta & & \\
\hline (Constant) & 12.219 & .796 & & 15.350 & .041 \\
$\mathrm{~d} 1 \mathrm{x} 12$ & $-.092-$ & .015 & $-1.070-$ & $-6.091-$ & .104 \\
$\mathrm{~d} 1 \mathrm{x} 13$ & $-.004-$ & .009 & $-.076-$ & $-.404-$ & .756 \\
$\mathrm{~d} 4 \mathrm{x} 13$ & $-9.177-$ & .968 & $-1.370-$ & $-9.485-$ & .067 \\
$\mathrm{~d} 5 \mathrm{x} 13$ & $-.302-$ & .038 & $-1.146-$ & $-7.929-$ & .080 \\
\hline
\end{tabular}

\section{9: The results of Bond market Stability indicators:}

Results are rejected economically for all estimators where the values are negative. According to Statistics the regression coefficients exception $\mathrm{d} 3 \mathrm{x} 14$ for Turkey significant according to $t$ test except. Although the value 
of $\mathrm{R}^{2}$ is high 0.64 but $\mathrm{f}$ test show that the regression relationship is insignificant, and $\mathrm{D}-\mathrm{W}=0.84$ statistics refers to that there are autocorrelation problem, these conflict in the results show clearly that there are multicollinearity. The results presented in table 7 as follow.

\section{Table:7 The results of Bond market Stability indicators}

\begin{tabular}{|l|c|c|c|c|c|}
\hline \multirow{2}{*}{ Model } & \multicolumn{2}{|c|}{} & \multicolumn{2}{c}{$\begin{array}{c}\text { Standardized } \\
\text { Coefficients }\end{array}$} & \multirow{2}{*}{ Sig. } \\
\cline { 2 - 4 } & Unstandardized Coefficients & Beta & & \\
\cline { 2 - 4 } (Constant) & 13.171 & 5.212 & & 2.527 & .039 \\
\hline $\mathrm{d} 2$ & $-11.046-$ & 24.830 & $-1.276-$ & $-.445-$ & .670 \\
\hline $\mathrm{d} 4$ & $-10.455-$ & 6.340 & $-1.304-$ & $-1.649-$ & .143 \\
\hline $\mathrm{d} 5$ & $-11.735-$ & 9.740 & $-1.464-$ & $-1.205-$ & .267 \\
\hline $\mathrm{d} 2 \times 14$ & .441 & 2.886 & .383 & .153 & .883 \\
\hline $\mathrm{d} 3 \times 14$ & $-.912-$ & .319 & $-1.563-$ & $-2.864-$ & .024 \\
\hline $\mathrm{d} 4 \times 14$ & $-.026-$ & .190 & $-.063-$ & $-.137-$ & .895 \\
\hline $\mathrm{d} 5 \times 14$ & .361 & 1.278 & .451 & .283 & .786 \\
\hline $\mathrm{d} 2 \times 14.1$ & $-1.614-$ & 5.263 & $-.211-$ & $-.307-$ & .768 \\
\hline $\mathrm{d} 3 \times 14.1$ & $-2.288-$ & 2.174 & $-.416-$ & $-1.052-$ & .328 \\
\hline $\mathrm{d} 4 \times 14.1$ & $-1.279-$ & 3.101 & $-.111-$ & $-.413-$ & .692 \\
\hline $\mathrm{d} 5 \times 14.1$ & .691 & 2.318 & .309 & .298 & .774 \\
\hline
\end{tabular}

\section{Conclusion:}

This study's main aim was to study the role of the Stock Markets in economic growth in emerging economies. Furthermore investigate whether stock market has played a significant role in promoting GDP growth rate in these emerging economies.

The empirical part examined the stock markets (equity market and Bond market), of five emerging economies in terms of size, efficiency, and stability. The regression was applied on panel data with the aid of a dummy variable which acted as a link between the observations. The results clearly show that equity market has played important role than bond market, beside 
that size market indicators role in interpret the growth in GDP is greater than efficient and stability indicators.

Furthermore, the $\mathrm{x} 1$ (Market Capitalization to GDP ratio (\%)) has important and significant role especially in Turkey, consequently with x4(New Capital Rose to Mkt. Cap. Ratio (\%) has significant effect in Turkey, India and Brazil. And X3(Equity Mkt. Turnover Ratio (\%), has important role in Turkey only, but x2(Trade Volume to GDP ratio (\%) has significant role in Malaysia and Egypt.

In addition, the role of efficiency for equity market indicators refers to that $\mathrm{x} 5$ (Stock return synchronicity) is the only efficiency indicator which is has important role in interpret the growth in GDP in India.

The results obtained from the equity market and stability indicators show that x8.1 (Equity Return Skew-ness) is the only indicator which is has significant role in Turkey and India.

It is important to relate the capacity of a stock market in relation to liquidity, diversification, and trading activities because high levels of liquidity offer substantial benefits to the financial system and overall economy through higher financial asset prices and a more efficient means to channel funds between savers and borrowers. Furthermore, Strong liquidity may also help to prevent imbalances in certain markets from spreading because of the greater dispersion of risks.

\section{In order for a stock market to be efficient:}

- tock prices should reflect primarily information about the fundamentals of corporations.

- It is vital for private information to be available publicly.

- The number of stale days (zero return) should be minimum compared to active trading days should be maximum. Therefore transaction costs such as direct costs and fees should be minimized.

For the stock market to be stable, volatility should be curbed. And opacity should be minimized because the higher the opacity, the less the stability.

Finally it is very important determinant of the size of the bond market which is the protection of creditor rights in a country. 


\section{References}

- Afonso, António, Ferreira, Raquel, Freitas, Edmund, Nóbrega, Celso and Pinheiro, José. (2002) "Intermediaries, Financial Markets and Growth: Some more International Evidence" December. < http://pascal.iseg.utl.pt/ depeco/wp/wp022003.pdf>.

- Baboo M Nowbutsing, (2009), " Stock Market Development and Economic Growth: The Case of Mauritius" International Business \& Economics Research Journal, Volume 8, Number 2.

- Baltagi, B. H. (1995), Econometric Analysis of Panel Data, New York: Wiley.

- Cheng Hsiao, (2003),"Analysis of Panel Data", Cambridge university press.

-De Rato, Rodrigo. "Economic growth and financial market development: a strengthening integration" .Emerging Markets, 23rd August 2000.

<http://www.imf.org/external/np/speeches/2007/082207.htm>.

- Del Valle, Clemente. "Developing Bond Markets: A Comprehensive View". < http://www.iadb.org/sds/doc/IFM-ClementeBond-E.pdf>.

- Duisenberg, Willem F. "The role of financial markets for economic growth", 31 May 2001.

<http://www.ecb.int/press/key/date/2001/html/sp010531.en.html>.

-Edwards, Franklin R. "Policies to Curb Stock Market Volatility" . <http://www.kc.frb.org/publicat/Sympos/1988/S88EDWAR.PDF>

-Ersel, Hasan, Kandil, Magda. (2000) "Thematic Paper on Markets and Growth for MENA Countries: Financial Markets”, March 3.

< http://www.gdnet.org/pdf/458_Kandil-Ersel.pdf>.

- Gujarati, D. N. (2004). "Basic econometrics", 4th ed., New York: McGraw-Hill Press.

- Hamid Mohtadi and Sumit Agarwal, (2001), " Stock Market Development and Economic Growth: Evidence from Developing Countries ", University of Wisconsin-Milwaukee, p, 7. 
- Har Wai Mun, Bandar Sungai Long and others,(2008), " Stock Market and Economic Growth in Malaysia: Causality Test", Asian social science, Vol. 4, No. 4.

- Hassan, Yasser, Roll, Richard. "The Development of Bond Market in Egypt", 2000.

$<$ http://www.iceg.org/NE/projects/financial/bond.pdf>.

- Heakal, Reem. "What Is An Emerging Market Economy?" July 30, 2003. \http://www.investopedia.com/articles/03/073003.asp>.

-Hsiao, C. (2003), "Analysis of Panel Data", Cambridge University Press, Second Edition.

-Hun Myoung Park, (2005)," Linear Regression Models for Panel Data Using SAS, STATA, LIMDEP, and SPSS", the Trustees of Indiana University.

-(Isenmila P.A and O. Akinola Adewale, (2012),_"The Role of Capital Market in Emerging Economy", International Journal of Business and Social Research, (IJBSR), Volume -2, No.-6.

- JALLOH MOHAMED, (2009), "The Role of Financial Markets in Economic Growth", Waifem Regional Course on Operations and Regulation of Capital Market, ACCRA, GHANA.

- Kindwell, David S., Peterson, Richard L., Blackwell, David W., Whidbee, David A. "Financial Institutions, Markets, and Money". Wiley, $8^{\text {th }}$ Edition, 2002, Ch3: 49-75; Ch22: 679-689.

-Krueger, Anne O. "Financial Markets and Economic Growth". September 28, 2006.

<http://www.imf.org/external/np/speeches/2006/092806.htm>.

- Laura Barbieri, "Panel Unit Root Tests: A Review".

- Levine, Ross, Beck, Thorston. "Stock Markets, Banks, and Growth:

Panel Evidence". Journal of Banking and Finance, 28, 2004, 423442.

<http://www.econ.brown.edu/fac/Ross_Levine/finance/rlevine/Publication/2 004_JBF_Panel\%20Evidence.pdf $>$.

- Levine, Ross, Zervos, Sara. "Stock Markets, Banks, and Economic Growth", American Economic Review, June 1998. 
<http://www.econ.brown.edu/fac/Ross_Levine/finance/rlevine/Publication/1 998_AER_Stock\%20Mkt\%20Banks\%20\&\%20Growth.pdf >.

- Levine, Ross. "Finance and Growth: Theory and Evidence." in Handbook of Economic Growth", Eds: Philippe Aghion and Steven Durlauf, the Netherlands: Elsevier Science, 2005.

. $<$ http://www.econ.brown.edu/fac/Ross_Levine/Publication/Forthcoming/Fo rth_Book_Durlauf_FinNGrowth.pdf $>$.

- Levine Ross, (1997), " Financial Development and Economic Growth: Views and Agenda", Journal of Economic Literature, Vol. 35, No. 2. pp. 688-726. http://links.jstor.org/sici?sici=00220515\%28199706\%2935\%3A2\%3C688\%3AFDAEGV\%3E2.0.CO\% 3B2-X

-Lin, Ying, Tzioumis, Konstantinos, "Financing Growth", World Bank, 2006.

< http://www.financial-indicators.org/resources/financing-growth.pdf >.

- Miller, M.H., "Financial markets and economic growth", Journal of Applied Corporate Finance, 11, 1998, pp. 8-14

- Mishkin, Fredric S. "The Economics of Money, Banking, and Financial Markets", Addison-Wesley, 5th Edition, 1999, Ch27: 692-699.

- Narayana, M. R. (2001), "Impact of Grants - in - Aid on Collegiate Education: Evidence and Implications of a Regional Study in India," http://epaa.asu.edu/epaa/v9n21

- Nicholas M Odhiambo,(2009), "Stock market development and economic growth in south Africa": An ARDL-bounds testing approach" , Department of Economics, University of South Africa.

-Pilbeam, Keith. "Finance and Financial Markets", Palgrave Macmillan, 1998, Ch1: 9-12; Ch10: 195-213.

- Randall K. Filer, Jan Hanousek and Do Stock Markets Promote Economic Growth?". Working Paper Number 267, p, 6. Nauro F. Campos, (2000),

- Robert Yafee, (2003), "A Primer for Panel Data Analysis" New York University. 
- Salvatore Capasso, (2006), "Stock Market Development and Economic Growth", Research Paper No. 2006/102, United Nation University, p, 5 .

- Soumya Guha Deb, and Jaydeep Mukherjee, (2008), "Does Stock Market Development Cause Economic Growth? A Time Series Analysis for Indian Economy", International Research Journal of Finance and Economics, Euro Journals Publishing, Inc. p, 143.

-Tabi Atemnkeng Johannes, Aloysius Mom Njong and Neba Cletus, (2011), "Financial development and economic growth in Cameroon, 1970-2005,(2011) Journal of Economics and International Finance Vol. 3(6), pp. 367-375.

http://www.academicjournals.org/JEIF

- ISSN 2006-9812 @2011 Academic Journals

- Todaro, Micheal P. "Economics for a Developing World". FT Prentice Hall, $3^{\text {rd }}$ edition, 1992, Ch25: 435-441.

-U1 Haque, Nadeem. "Developing of Financial markets in Developing

Economies". March 18,2002

Shttp://www.imf.org/external/country/lka/rr/031802a.htm .

-Warsh, Kevin M. "Market Liquidity: Definitions and Implications".2007. $\leq \mathrm{http}: / / \mathrm{www}$. federalreserve.gov/newsevents/spe ech/Warsh20070305a.htm>.

-World Bank, 2006. "Bond market development indicators - Financial Sector Operations and Policy",

$\leq$ http://siteresources.worldbank.org/INTTOPACCFINSER/Resources/Bndin d.pdf $\geq$.

-World Bank, 2006. "Equity market indicators: A primer." Financial Sector Operations and Policy",.

$\leq$ http://siteresources.worldbank.org/INTTOPACCFINSER/Resources/Equit y_Primer.pdf>

•Yongfu Huang, (2005) "What determines financial development?", Discussion Paper No. 05/580. 